\title{
COMPARATIVE ASSESSMENT OF ARTIFICIAL SWEETENERS TOXICITY VIA EXPRESS BIOTEST
}

\author{
A.V. Samoilov ${ }^{1}$, N.M. Suraeva ${ }^{1}$, M.V. Zaitseva ${ }^{1,2}$, M.N. Kurbanova ${ }^{1}$, V.V. Stolbova ${ }^{2}$ \\ ${ }^{1}$ V.M. Gorbatov's Federal Scientific Center for Nutrition Systems, RAS, 78 Shkolnaya Str., Vidnoe, 142703, \\ Russian Federation \\ ${ }^{2}$ Moscow State University, 12 Bldg., 1 Leninskie Gory, Moscow, 119991, Russian Federation
}

Various food additives are being produced and consumed by population in greater and greater quantities and risks of probable toxic effects exerted by them are growing as well. These additives frequently occur in various combinations in food products and the environment, they can be consumed for a long period of time and produce hazardous mutagenic and carcinogenic effects. Therefore, it is extremely vital to assess combined impacts exerted by food additives so that their safety would be proven. There are certain advantages related to vegetative test-systems and cytogenetic analysis procedures for biological tests data when it comes to screening for toxic and mutagenic effects produced by chemicals. Allium-test which applies Allium cera bulb onion roots as a test-object is quite distinctive. When compared with other tests that employ animals and various cell cultures, this test turns out to be less complicated and costly and more sensitive as well.

Our research goal was to examine influences exerted by such artificial sweeteners as aspartame and sucralose on living weight gain and mitotic anomalies frequency in apical meristem cells in Allium cera bulb onion roots. We also assessed a synergy effect caused by combined exposure to both these chemicals. We detected that aspartame caused a significant decrease in root living weight against the control while there were no toxic effects caused by sucralose. Maximum toxicity was detected when a test-system was exposed to both artificial sweeteners together and it was considered to result from the above mentioned synergy effect. Chromosome aberrations frequency in test samples differed insignificantly from the control but we also detected authentic changes in chromosome anomalies spectrum in root meristem cells. Disorders in chromosome disjunction and anomalies in the mitotic apparatus were the most frequently registered ones.

Key words: sucralose, aspartame, Allium cepa, biological testing, cytogenetic analysis, toxicity, chromosome aberrations, anomalies in the mitotic apparatus.

Aspartame and sucralose are popular artificial sweeteners; they are applied in manufacturing a wide range of food products such as soft drinks, confectionary, chewing gum, dairy products, jams, various sauces and flavors as well as low-calorie products. Aspartame is an artificial synthesized chemical, namely Laspartil-L-phenylalanine. It dissolves in water quite well, is 200 times sweeter than saccharose, and can't be used in food products that are to be thermally treated as it is usually destroyed under heating and loses its sweet taste. Sucralose (trichlorogalactosaccharose), an- other widely spread artificial sweetener, is obtained from saccharose via chemical transformation. It is thermally stable and is quite like usual sugar in its taste but still it is 600 times sweeter than saccharose. These sweeteners were officially approved by Food and Drug Administration in 1981 and 1998 respectively. Aspartame is applied as a sweetener in more than 90 countries and in manufacture of 6,000 various food products [1]. Sucralose is detected to be applied in more than 70 countries worldwide. Besides, sucralose, due to high chemical stability of its molecule and good

(C) Samoilov A.V., Suraeva N.M., Zaitseva M.V., Kurbanova M.N., Stolbova V.V., 2019

Artem V. Samoilov - candidate of biological sciences, head of laboratory of quality and safety of food products (e-mail: molgen@vniitek.ru; tel.: +7 (495) 541-87-00; ORCID: https://orcid.org/0000-0001-5655-174X).

Natal'ya M. Suraeva - doctor of biology, chief researcher inlaboratory of quality and safety of food products (e-mail: nsuraeva@yandex.ru; tel.: +7 (495) 541-87-00; ORCID: https://orcid.org/0000-0002-0144-8128).

Mariya V. Zaitseva - junior researcher in laboratory of quality and safety of food products (e-mail: mascha.zajtseva2014@yandex.ru; tel.: +7 (495) 541-87-00; ORCID: https://orcid.org/0000-0002-6624-883X).

Madinat N. Kurbanova - candidate of biological sciences, senior researcher inlaboratory of quality and safety of food products (e-mail: sk5969@yandex.ru; tel.: +7 (495) 541-87-00; ORCID: https://orcid.org/0000-0001-5798-554X).

Valeriya V. Stolbova - candidate of biological sciences, senior lecturer, department of radioecology and ecotoxicology, faculty of soil science (e-mail: vstol@bk.ru; tel.: +7 (495) 939-22-11; ORCID: https://orcid.org/0000-0001-5433-5533). 
water solubility, is considered a potential environmental pollutant. Sucralose has already been found in water basins in some countries and even in the Gulf Stream in the Atlantic in concentrations within $0.1-1.0 \mathrm{~g} / \mathrm{l}$; therefore, there is an issue related to probable risks of technogenic environmental pollution with the substance [2].

Food products manufacturing is permanently growing and population tend to consume more and more variable food additives; given that, health risks related to such additives and risks of probable environmental pollution with them are also increasing substantially. Data on artificial sweeteners safety have been analyzed in foreign literature and the results are rather controversial. Tests were performed on models of human cells cultures, animal cells cultures, bacteria, and on laboratory animals. Most publications in early periods confirmed aspartame and sucralose to be safe provided that existing consumption standards were met; conclusions were made due to no genotoxic and acute toxic effects being detected via standard tests; although there were some works mentioning that the substances could induce chromosome aberrations [1, 3-7]. However, over recent years new facts about toxic effects produced by these sweeteners have been discovered, and, consequently, it was recommended to strictly control their consumption. Thus, sucralose was considered to be hazardous for human health due to its chlorinated structure as it is well-known that chlorinated sugar and products of its hydrolysis that are quite similar to sucralose in their structure destroy nerve cells. In vitro research performed on human liver cells allowed to detect that sucralose reacted with reduced B12 vitamin and such reactions were suggested to influence metabolism of the vitamin [2]. Negative influence exerted by artificial sweeteners, sucralose included, on intestinal microbiota was also confirmed; this influence resulted in dysbacteriosis and inflammatory reactions in mice's livers [8]. According to literature data, even more serious consequences for health can be caused by aspartame contents in food products. It was shown that when aspartame was added into drinking water during 2 months, it led to damages to rats' livers due to induced hyperglycemia and accumulation of various lipids under oxidative stress [9]. Histological and immune-histochemical research on generative tissues of rats that had aspartame in their ration revealed significant disorders in placenta and fetal tissues [10]. It was also revealed that chronic consumption of aspartame, especially at earlier stages in development and during long-term periods, could cause changes in the nervous system, astrogliosis, and lower vital capacity of prefrontal cortex neurons, tonsil, hippocampus, and hypothalamus in rats [11].

It should be noted that ideal test-systems applied to imitate human or animal detoxification systems and metabolism of chemical compounds haven't been created yet. And unreasonably little attention has been paid to mechanisms of systemic (combined) effects produced by negative factors on a test-organism; therefore, new trends in strategic planning of test procedures are aimed at making changes into toxicity assessment algorithms as regards mixtures and food matrices [12]. The examined sweeteners can often be consumed together as they occur in various food products; therefore, they can produce both additive and synergic negative effects on a human body. So, to assess safety of impacts exerted by synthetic compounds, nowadays it is truly vital to apply a complex approach that can be implemented with express-biotests being added into a set of test techniques.

Vegetative test-systems have certain advantages as regards complex screening of toxic, cytotoxic, and mutagenic effects; Allium-test is a specific one among such tests. The test uses Allium cepa bulb onion roots as a test-object and its test-function is changes in length/living weight, as well as some cytological and cytogenetic parameters of cells in the apical meristem. At present this test is recommended by WHO experts as a standard one to be applied in cytogenetic environmental monitoring. Moreover, the method was also successfully tested to examine a wide range of factors, such as ionizing and non-ionizing radiation [13-16], food additives [17], herbi- 
cides [18], medications [19], and even antimutagenic potential [20]. When compared with other tests that employed animal and vegetative cell cultures, Allium-test turned out to be more sensitive [21], and reliability of data on mutagenicity obtained with it is usually beyond question as there are very few false-negative results [22]. We assume that tests on aspartame and sucralose in in vivo experiments with Allium-test will allow to obtain new data on biological effects produced by these widely used food additives.

Our research goal was to examine toxicity and genotoxicity of aspartame and sucralose and their combination with two Allium-test modifications.

Data and methods. We applied the following sweeteners in our experiments: sucralose (Alfa Aesarby Thermo Fisher Scientific) and aspartame (Alfa Aesar by Thermo Fisher Scientific). Our test-organisms were Allium cepa $L$ bulb onions (Schtutgarten sort) of the same size (diameter 2.5-3 cm) and weight (5-7 grams). Onions didn't have green leaves. Prior to incubation, we removed dried peels from onions. Then, onions from the control groups were put in to $10-\mathrm{ml}$ vials with bottled drinking water; onions from test groups were put into sweeteners solutions in the same water in concentrations equal to $1 \mathrm{~g} / 1$ and $2 \mathrm{~g} / 1$ each, and their combinations in concentrations equal to $0.5 \mathrm{~g} / 1$ and $1 \mathrm{~g} / 1$. Concentrations of sweeteners in solutions didn't exceed domestic standards for their contents in food products. Both test and control groups were incubated in darkness under $25^{\circ} \mathrm{C}$ for 5 days. Solutions in vials were refreshed daily. After incubation was over, roots were cut off from each onion, fluid was removed off them with filter paper; onions were them weighed and used to perform cytogenetic analysis of cells from the apical meristem. Preparations were then dried with acetoorcein (1 gram of orcein was dissolved in $50 \mathrm{ml}$ of $\left.45-\% \mathrm{CH}_{3} \mathrm{COOH}\right)$. In order to preserve roots for a long time, we stored than in $70 \%$ ethanol. Then we prepared instant squash preparations and analyzed them with Axioskop 40 (Zeiss) light microscope. About 17,000 cells were viewed with a microscope during cytogenetic research. Obtained results were statistically processed with Microsoft Excel and Statistica, mean values were compared with Student's T-test and Fischer's transformation; we also compared two samplings with non-parametric Chi-square criterion.

Results and discussion. To assess toxic, mitosis-modifying and genotoxic effects produced by aspartame and sucralose with Alliumtest, we examined the following parameters: a growth in root living weight under various concentrations and combinations of sweeteners, mitotic index, frequency and range of chromosome aberrations. Besides, we applied two Allium-test modifications, with preliminary 2-day sprouting and further selection of onions with their root length being not shorter than $1 \mathrm{~cm}$ (the first and the second modification accordingly) and without preliminary sprouting. We assume that this set of parameters allows to achieve the most valid detection of different physiological and cytogenetic disorders reflecting overall toxic effects and cyto-(geno) toxic ones respectively. We'd like to dwell a bit more on toxicity parameters as a conventional Allium-test techniques involved measuring root length to assess them, but we chose living weight instead. It has a number of advantages, including higher sensitivity [23]. We also tested combinations of these two substances in order to reveal hidden potential of their toxicity as a synergic effect occurrence.

As we can see from Tables 1 and 2, we detected authentic discrepancies between test and control groups related to a smaller growth in root living weight in onions treated with aspartame solution; these discrepancies were detected in both test modifications. Sucralose didn't have any toxic effects.

When assessing effects produced by mixtures of these two substances, we obtained significant results in the second test modification. Aspartame in concentration equal to $1 \mathrm{~g} / \mathrm{l}$ led to an authentic almost 2-time decrease in root living weight against the control group, but if sucralose was added in the same concentration, then mixture toxicity authentically grew by more than 4 times. Moreover, the 
Effects produced by sweeteners on a growth in root living weight, mitotic activity and frequency of chromosome aberrations in apical meristem cells of onion roots in the first test modification $(n=6)$

\begin{tabular}{|l|c|c|c|c|}
\hline \multirow{2}{*}{ A test variant } & \multirow{2}{*}{$\begin{array}{c}\text { Average root } \\
\text { weight per an } \\
\text { onion, grams }\end{array}$} & \multirow{2}{*}{$\begin{array}{c}\text { Mitotic } \\
\text { index, \% }\end{array}$} & \multicolumn{2}{c|}{$\begin{array}{c}\text { Chromosome aberrations } \\
\text { recalculated per, \% }\end{array}$} \\
\cline { 4 - 5 } & $0.217 \pm 0.061$ & 5.91 & 0.29 & 4.83 \\
\hline Control & $0.228 \pm 0.049$ & 6.23 & 0.34 & 5.45 \\
\hline Sucralose, $1 \mathrm{~g} / 1$ & $0.281 \pm 0.081$ & 6.26 & $0.96^{*}$ & $15.36^{*}$ \\
\hline Sucralose, $2 \mathrm{~g} / 1$ & $0.161 \pm 0.047$ & $4.28^{*}$ & $0.55^{*}$ & $12.77^{*}$ \\
\hline Aspartame, $1 \mathrm{~g} / 1$ & $0.108 \pm 0.041^{* *}$ & $4.65^{*}$ & 0.29 & $6.31^{*}$ \\
\hline Aspartame, $2 \mathrm{~g} / 1$ & $0.101 \pm 0.039^{* *}$ & $6.95^{*}$ & 0.33 & 4.72 \\
\hline Sucralose + Aspartame, $0.5 \mathrm{~g} / 1$ & $0.76^{*}$ & 0.23 & 4.79 \\
\hline Sucralose + Aspartame, $1 \mathrm{~g} / 1$ & $0.115 \pm 0.036^{* *}$ & $4.76^{*}$ & \\
\hline
\end{tabular}

Note: * means $\mathrm{p}<0.05 ; * *$ means $\mathrm{p}<0.2$.

Table 2

Effects produced by sweeteners on a growth in root living weight, mitotic activity and frequency of chromosome aberrations in apical meristem cells of onion roots in the second test modification $(n=5)$

\begin{tabular}{|c|c|c|c|c|}
\hline \multirow{2}{*}{ A test variant } & \multirow{2}{*}{$\begin{array}{l}\text { Average root weight } \\
\text { per an onion, grams }\end{array}$} & \multirow{2}{*}{$\begin{array}{l}\text { Mitotic } \\
\text { index, \% }\end{array}$} & \multicolumn{2}{|c|}{ Chromosome aberrations recalculated per, $\%$} \\
\hline & & & Overall number of cells & Dividing cells \\
\hline Control & $0.469 \pm 0.070$ & 12.05 & 1.24 & 10.26 \\
\hline Sucralose, $1 \mathrm{~g} / 1$ & $0.429 \pm 0.100$ & 12.44 & 1.13 & $9.09 *$ \\
\hline Sucralose, $2 \mathrm{~g} / \mathrm{l}$ & $0.478 \pm 0.064$ & $14.37 *$ & 1.82 & $12.65^{*}$ \\
\hline Aspartame, $1 \mathrm{~g} / 1$ & $0.206 \pm 0.045^{*}$ & $14.62 *$ & 1.34 & 9.19 \\
\hline Aspartame, $2 \mathrm{~g} / 1$ & $0.224 \pm 0.043^{*}$ & $15.49 *$ & $1.73^{*}$ & 11.18 \\
\hline $\begin{array}{l}\text { Sucralose }+ \text { As- } \\
\text { partame, } 0.5 \mathrm{~g} / 1\end{array}$ & $0.245 \pm 0.141 *$ & $16.55^{*}$ & 1.31 & $7.93 *$ \\
\hline $\begin{array}{l}\text { Sucralose + As- } \\
\text { partame, } 1 \mathrm{~g} / 1\end{array}$ & $0.140 \pm 0.027 *$ & $9.72 *$ & $0.82 *$ & $8.48 *$ \\
\hline
\end{tabular}

Note: * means $\mathrm{p}<0.05$.

effect was dose-dependent. So, these data proved there was a systemic synergic effect that made a mixture of two chemical substances more toxic than each of them separately. It is especially alarming as these two chemicals can be introduced together into a body or occur as environmental pollutants in different combinations.

It is known that deviations in mitotic index of test-organisms, both towards growing or falling, are signs that a test medium is cytotoxic [24]. We analyzed this parameter in test groups exposed to aspartame in both test modifications and detected statistically significant discrepancies in its values against control sam- ples (Tables 1 and 2); it was lower in the first test modification and higher in the second one. As for samples exposed to sucralose, an authentic discrepancy was detected only in the second test modification and high concentration of this sweetener. Therefore, we detected a mitotoxic effect in samples exposed both to aspartame and sucralose but it was insignificant as a share of mitotic cells in all test groups had insignificant statistical discrepancies form control groups (less than 40\%), while food preservatives and flavor enhancers can reduce this parameter by several times [25].

A share of chromosome aberrations after exposure to aspartame and sucralose, both 
separately and in a combination, remained low in both test modifications. We also didn't detect any dose-dependent effects (Tables 1 and 2). These data are quite consistent with other research results proving that these two substances didn't have any genotoxic effects [26]. We analyzed a range of chromosome aberrations as a probable outcome of adaptation reorganizations caused by impacts exerted by these substances or as a sign that their impacts were quite specific (Figure 1).

We distributed all the detected aberrations into the following groups: group A included disorders in chromosome disjunction (forwarding or lagging); group B, mitotic apparatus anomalies (adhesion, multi-polar mitosis); group $\mathrm{C}$, aberrations reflecting clastogene effects by a factor (bridges, fragments); group D, other aberrations (chromosome fragmentation, agglutination, or pulverization) respectively. It turned out that there were no authentic discrepancies between test and control groups detected in the first test modification, while in the second one almost all test samples had authentic discrepancies from control ones, and disorders were predominantly in groups A and B (Figure). And the most significant discrepancies were again detected in samples exposed to a combination of aspartame and su- cralose in $1 \mathrm{~g} / 1$ concentration just as it was with root living weight measuring.

According to these data, aspartame and a combination of aspartame and sucralose within fixed standards for their contents in food products produced an authentic dose-dependent toxic effect. The results were obtained mostly via examining microscopic parameters, namely a growth in root living weight, as this parameter reflected a sum of all distorting effects and, therefore, was more sensitive than other microscopic parameters [17]. So, the above-mentioned literature data on these sweeteners determined in animal experiments to be health risk factors have also been confirmed by the present work by a vegetative biotest. In this context, arguments that call for reducing recommended permissible safe doses of aspartame in food products seem even more convincing [27].

Conclusion. We exposed onions to aspartame in two Allium-test modifications and analyzed a growth in root living weight; it allowed us to come to a valid conclusion that aspartame was toxic in a dose equal to $1 \mathrm{~g} / 1$ (50\% delay in a living weight growth against the control). We didn't detect any similar effects when samples were exposed to sucralose. All the examined doses didn't exceed hygienic standards for contents of these substances in

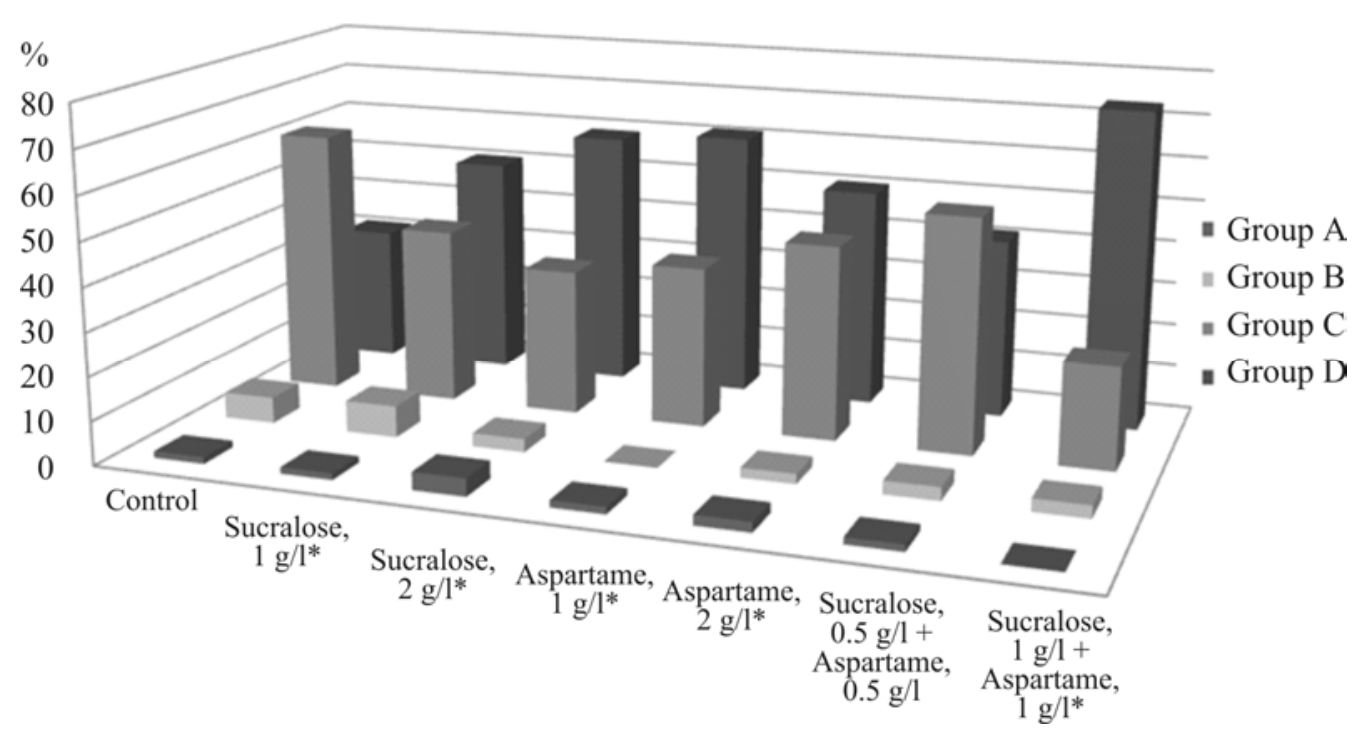

Figure 1. Distribution of chromosome aberrations as per groups in the second test modification $(\%),{ }^{*}$ means $\mathrm{p}<0.05$ 


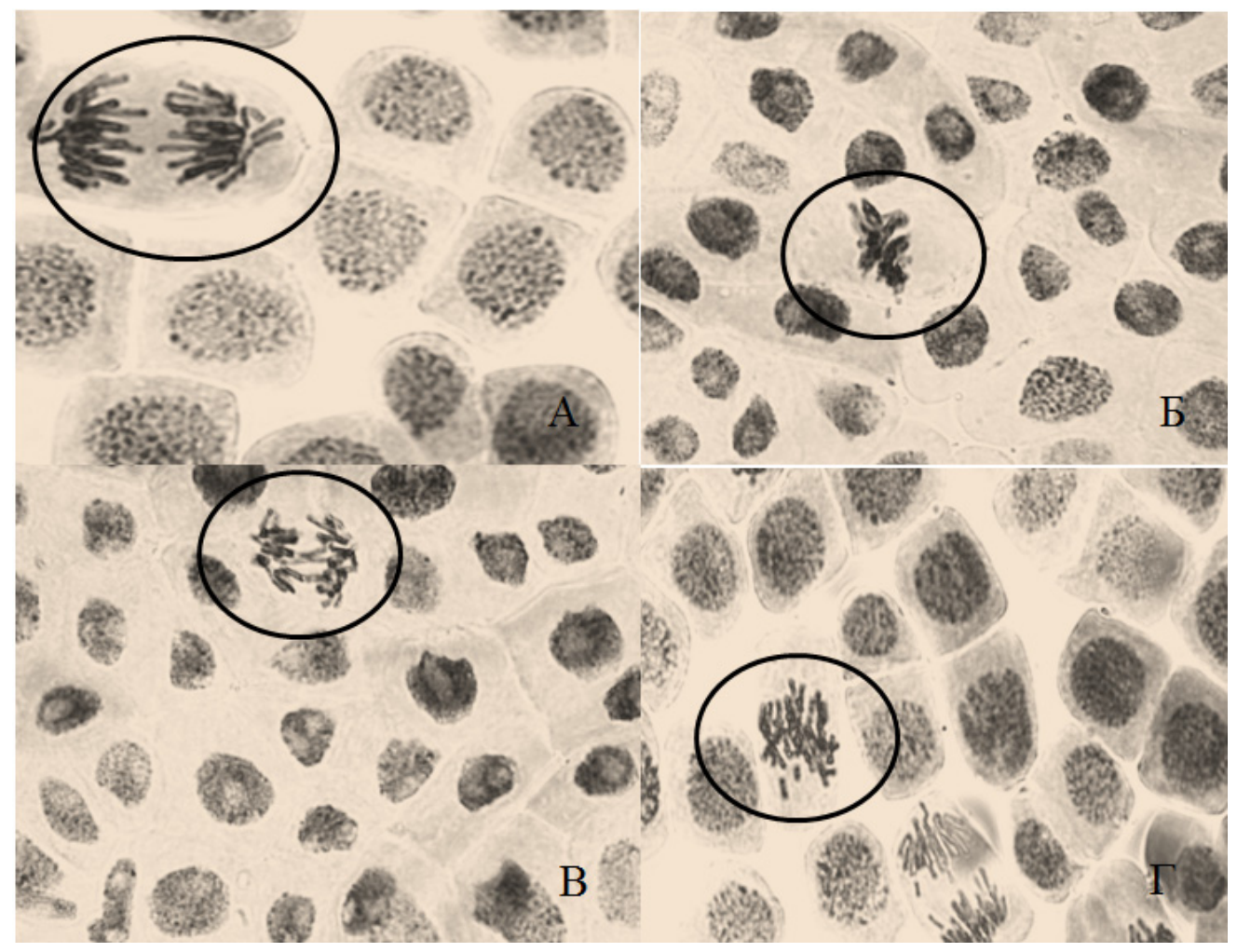

Figure 2. Dried preparations of onion meristem cells. A is forwarding in anaphase, $\mathrm{B}$ is adhesion in metaphase, $\mathrm{C}$ is a bridge in anaphase, $\mathrm{D}$ is fragmentation in metaphase

food products. We were the first to obtain some data on combined effects produced by these sweeteners and to register a synergic effect. It was revealed that these chemicals exerted an authentic impact on a range of chromosome aberrations in meristem cells against the control. It turned out that the most informative results as regards assessing the above mentioned toxicity and genotoxicity parameters were obtained via Allium-test with preliminary sprouting (the second modification).
The obtained results are consistent with an above-mentioned theoretical assumption that a mixture of aspartame and sucralose would be more toxic than each of them separately, and it should be taken into account when hygienic standards for contents of these substances in food products are developed.

Funding. The research was not granted any sponsor support.

Conflict of interests. The authors state there is no any conflict of interests.

\section{References}

1. Kirkland D., Gatehouse D. Aspartame: A review of genotoxicity data. Food and Chemical Toxicology, 2015, vol. 84, pp. 161-168. DOI: 10.1016/j.fct.2015.08.021

2. Eriksson Wiklund A.-K., Adolfsson-Erici M., Liewenborg B., Gorokhova E. Sucralose induces biochemical responses in Daphnia magna. PLOS ONE, 2014, vol. 9, no. 4, e92771 p. DOI: 10.1371/journal.pone.009277

3. Durnev A.D., Orishchenko A.V., Kulakova A.V., Beresten' N.F., Seredin S.B. Clastogenic activity of dietary sugar substitutes. Voprosy meditsinskoi khimii, 1995, vol. 41, no. 4, pp. 31-33.

4. Sasaki Y.F., Kawaguchi S., Kamaya A., Ohshita M., Kabasawa K., Iwama K. [et al.]. The comet assay with 8 mouse organs: results with 39 currently used food additives. Mutat Res, 2002, no. 519 , pp. $103-119$. 
5. Rencüzoğullari E., Tüylü B., Topaktas M., Basri I., Kayraldiz A. Genotoxicity of Aspartame. Drug and Chemical Toxicology, 2004, vol. 3, no. 27, pp. 257-268. DOI: 10.1081/DCT-120037506

6. Sharma A., Panwar S., Singh A.K., Jakhar K.K. Studies on the genotoxic effects of sucralose in laboratory mice. Indian Journal Of Animal Research, 2007, vol. 1, no. 41, pp. 1-8.

7. Brusick D., Grotz V.L., Slesinski R., Kruger C.L., Hayes A.W. The absence of genotoxicity of sucralose. Food and Chemical Toxicology, 2010, vol. 11, no. 48, pp. 3067-3072.

8. Liu C.W., Chi L., Tu P., Xue J., Ru H., Lu K. Quantitative proteomics reveals systematic dysregulations of liver protein metabolism in sucralose-treated mice. J Proteomics, 2019, vol. 196, pp. 1-10. DOI: 10.1016/j.jprot.2019.01.011

9. Lebda M.A., Tohamy H.G., El-Sayed Y.S. Long-term soft drink and aspartame intake induces hepatic damage via dysregulation of adipocytokines and alteration of the lipid profile and antioxidant status. Nutr. Res., 2017, vol. 41, pp. 47-55.

10. Shalaby A.M., Ibrahim MAAH., Aboregela A.M. Effect of aspartame on the placenta of adult albino rat. A Histological and Immunohistochemical Study. Ann. Anat., 2019, vol. 224, pp. 133-141. DOI: 10.1016/j.aanat.2019.04.007

11. Solis-Medina A., Martínez-Magaña J.J., Quintanar-Jurado V., Gallegos-Silva I. [et al.] Astrogliosis and decreased neural viability as consequences of early consumption of aspartameand acesulfame potassium in male Wistar rats. Metab. Brain Dis., 2018, vol. 33, no. 6, pp. 2031-2038.

12. Blaauboer B.J., Boobis A.R., Bradford B., Cockburn A., Constable A., Daneshian M. [et al.]. Considering new methodologies in strategies for safety assessment of foods and food ingredients. Food and Chemical Toxicology, 2016, pp. 19-35. DOI: 10.1016/j.fct.2016.02.019

13. Saghirzadeh M., Gharaati M. R., Mohammadi Sh., Ghiassi-Nejad M. Evaluation of DNA damage in the root cells of Allium cepa seeds growing in soil of high background radiation areas of Ramsar-Iran. Journal of Environmental Radioactivity, 2018, vol. 99, no. 10, pp. 1698-1702.

14. Pesnya D.S., Romanovsky A.V., Prokhorova I.M. Working out technique for estimating the influence of UHF-radiation of cell telephones and other devices with EMR RF on organisms in vivo. Yaroslavskii pedagogicheskii vestnik, 2010, no. 3, pp. 80-84.

15. Oudalova A.A., Geras'kin S.A., Dikarev V.G., Dikareva N.S. Assessment of cyto- and genotoxicity of natural waters in the vicinity of radioactive waste storage facility using Allium test. Radiation biology. Radioecology, 2014, vol. 54, no. 1, pp. 97-106.

16. Oudalova A.A., Pyatkova S.V., Geras'kin S.A., Kiselev S.M., Akhromeev S.V. Assessment of cyto and genotoxicity of underground waters from the far Eastern Center on Radioactive Waste Treatment Site. Radiation biology. Radioecology, 2016, vol. 2, no. 56, pp. 208-219. DOI: 10.7868/S0869803116020132

17. Pandey H., Kumar V., Roy B.K. Assessment of genotoxicity of some common food preservatives using Allium cepa L. as a test plant. Toxicology Reports, 2014, no. 1, pp. 300-308. DOI: 10.1016/j.toxrep.2014.06.002

18. Yildiz M., Evrim S.A. Genotoxicity testing of quizalofop-P-ethyl herbicide using the Allium cepa anaphase-telophase chromosome aberration assay. Caryologia, 2008, vol. 1, no. 61, pp. 45-52. DOI: 10.1080/00087114.2008.10589608

19. Tulay A.C., Oslem S.A. Evaluation of cytotoxicity and genotoxicity of inula viscosa leaf extracts with Allium test. Journal of Biomedicine and Biotechnology, 2010, vol. 2010, 8 p.

20. Loganathan P.K., Natarajan P. G2 studies of antimutagenic potential of chemopreventive agent curcumin in Allium cepa root meristem cells. Facta Universitatis, series: Medicine and Biology, 2008, vol. 1, no. 15, pp. 20-23.

21. Fiskesjo G. The Allium Test as a standard in environmental monitoring. Hereditas, 1985, vol. 102, pp. 99-112. DOI: 10.1111/j.1601-5223.1985.tb00471.x

22. Onwuamah C.K., Ekama S.O., Audu R.A., Ezechi O.C., Poirier M.C. [et al.]. Exposure of Allium cepa root cells to zidovudine or nevirapine induces cytogenotoxic changes. PLoS ONE, 2014, vol. 3, no. 9, e90296 p. DOI: 10.1371/journal.pone.0090296

23. Kurbanova M. N., Suraeva N.M., Rachkova V.P., Samoylov A.V. Comparative study of indicators of toxic activity in the Allium-test. Agrarnii vestnik Urala, 2018, no. 171 (4), pp. 20-25. 
24. Leme D.M., Marin-Morales M.A. Allium cepa test in environmental monitoring: A review on its application. Mutation Research, 2009, vol. 1, no. 682, pp. 71-81. DOI: 10.1016/j.mrrev.2009.06.002

25. Nunes R.D.M., Sales I.M.S., Silva S.I.O., Sousa J.M.C., Peron A.P. Antiproliferative and genotoxic effects of nature identical and artificial synthetic food additives of aroma and flavor. Braz. J. Biol, 2017, vol. 1, no. 77, pp. 150-154. DOI: 10.1590/1519-6984.12115

26. Olusegun E. Adegoke T., Adegoke O.A. Toxicity of food colours and additives: A review. African Journal of Pharmacy and Pharmacology, 2015, vol. 9, no. 36, pp. 900-914. DOI: 10.5897/AJPP2015.4385

27. Choudhary A.K., Pretorius E. Revisiting the safety of aspartame. Nutr Rev, 2017, vol. 75, no. 9 , pp. $718-730$. DOI: $10.1093 /$ nutrit/nux035

Samoilov A.V., Suraeva N.M., Zaitseva M.V., Kurbanova M.N., Stolbova V.V. Comparative assessment of artificial sweeteners toxicity via express biotest. Health Risk Analysis, 2019, no. 2, pp. 83-90. DOI: 10.21668/health.risk/2019.2.09.eng

Received: 20.03.2019

Accepted: 14.06.2019

Published: 30.06 .2019 